\title{
Risk-Informed Selection of Steel Connections for Seismic Zones
}

\author{
Selección de conexiones de acero para zonas sísmicas \\ basada en información de riesgo
}

\author{
De León-Escobedo D. \\ Facultad de Ingeniería \\ Universidad Autónoma del Estado de México \\ E-mail:daviddeleonescobedo@yahoo.com.mx
}

Reyes-Salazar A.

Facultad de Ingeniería

Universidad Autónoma de Sinaloa

E-mail: reyes@uas.uasnet.mx

Información del artículo: recibido: agosto de 2008, aceptado: noviembre de 2010

\begin{abstract}
The findings about the fragile behavior of steel welded connections after the Northridge 1994 earthquake, specially for frames designed to withstand lateral force, has brought an amount of new attention to the design and safety issues of the welded connections for structures located on seismic zones. In México, practitioners and designers are wondering about the seismic effectiveness of the several kinds of connections as used in steel structures. A decision must be made to balance the safety required with the costs incurred after exceeding the serviceability limit state. Structural reliability techniques provide the proper framework to include the inherent uncertainties into the design process. Registered motions after the 1985 Mexico City earthquake are properly scaled according to the seismic hazard curve for soft soil in Mexico City. Earthquake occurrence is modeled as a Poisson process and the expected life-cycle cost is taken as the decision criteria. Parametric analyses allow the identification of dominant variables and ranges where one option is more recommendable than the other one. The proposed formulation may support designers and builders for the decision making process about the selection of the convenient connection type for the seismic zones with soft soil in Mexico City.
\end{abstract}

\section{Keywords:}

- bolted and welded connections

- seismic response

- life-cycle expected cost

- seismic risk 


\section{Resumen}

Los hallazgos del comportamiento frágil de conexiones soldadas de acero después del temblor de Northridge de 1994, especialmente para marcos diseñados para resistir cargas laterales, ha traído la atención en los aspectos de seguridad y diseño de conexiones soldadas para estructuras localizadas en zonas sísmicas. En México, ingenieros de la práctica y diseñadores se están preguntando cuál será la efectividad sísmica de varias alternativas de conexiones utilizadas en estructuras de acero. Se deben tomar decisiones para equilibrar el nivel requerido de seguridad con los costos en que se incurre cuando se excede un estado límite. Las técnicas de confiabilidad estructural proveen el marco adecuado para incluir explícitamente las incertidumbres inherentes al proceso de diseño. Movimientos del terreno registrados en el temblor de la Ciudad de México de 1985 se escalan apropiadamente de acuerdo a la curva de riesgo sísmico de la zona de suelo blando de México, DF. La ocurrencia de temblores se modela de acuerdo a un proceso de Poisson y se toma como criterio de decisión el costo esperado en el ciclo de vida. El análisis paramétrico permite la identificación de variables dominantes y se identifican rangos en los que una opción, de las conexiones propuestas, es más recomendable que la otra. La formulación propuesta puede apoyar a diseñadores y constructores en el proceso de toma de decisiones acerca de la selección del tipo conveniente de conexión para zonas sísmicas como la Ciudad de México.

\section{Introduction}

Steel buildings are a common design solution for seismic zones. However, the selection of the appropriate connection type is still an issue in Mexico. Special interest has been raised about the fragile behavior of welded connections, especially after the amount of damages experienced due to the Northridge earthquake (Bruneau et al., 1998) occurred in California in 1994. The SAC Project (SAC project, 1994), developed in the US under FEMA's coordination, provided some insight to improve the understanding of the seismic behavior of welded connections (FEMA, 273, 1997, Wen et al., 1997). In Mexico, some efforts have been made to derive practical recommendations for steel connections (IMCA, 1997, Miranda, 1997a, Miranda, 1997b and Miranda et al., 1999).

Alternate loading is an important factor to produce cumulative damage (Esteva, 1966) and, recently, the fracture mechanism of typical connections have been studied under the light of reliability analyses (Righiniotis et al., 2004)

Usually the collapse limit state is emphasized to provide design recommendations (Gobierno del D.F., 2004; AISC, 2005) but, given the character and extension of the damage produced by some earthquakes and the time the structure is off-service during repairs, the serviceability condition is also a concern.
Structural reliability and life-cycle costing (Ang et al., 1997) serve as the measuring tools to weigh the cost/ benefit relevance of the various connection alternatives and to balance the trade-off between required safety and costs of the damage consequences.

A seismic hazard curve, previously developed for Mexico City (Esteva et al., 1989) is used with scaling factors to assess the seismic vulnerability of the structures.

Given that the connection forces due to the seismic environment are uncertain, statistics of the maximum acceleration demands are obtained at the connection location for a typical building throughout Monte Carlo simulation and, with these statistics and the connection model, statistics of the maximum responses are obtained. Maximum moment and maximum shear forces histograms are obtained with these statistics and, using the limit state function appropriate for the given connection type, probabilities of failure and damage are obtained for both demand levels: extreme and operational earthquakes. These probabilities are introduced into the life-cycle cost/benefit relationship for several connection types and the optimal type is obtained by comparing the expected life-cycle costs. The minimum expected life-cycle cost corresponds to the optimal connection type. Damage costs include the repair cost and losses related to the potential fatalities, injuries and business interruption. 
The results may also be used, after further refinements, to update the design specifications for seismic zones in Mexico.

\section{Formulation of the decision criteria}

The expected life-cycle cost is usually calculated to assess the economic effectiveness of potential structural solutions and come up to optimal decisions under uncertain loading conditions (Neves et. al., 2003; Ang et al., 2005).

Two alternative connection types are proposed and their performances are compared from the viewpoints of structural reliability and costs. The expected life-cycle cost $E\left[C_{T}\right]$ is composed by the initial cost $C_{i}$ and the expected damage costs $E\left[C_{D}\right]$ :

$$
E\left[C_{T}\right]=C_{i}+E\left[C_{D}\right]
$$

The expected damage costs include the components of damage cost: expected repair $E\left[C_{r}\right]$, injury $E\left[C_{i n j}\right]$ and fatality $E\left[C_{f a t}\right]$ costs and each one depends on the probabilities of damage and failure of the structure. These component costs of damage are defined as:

$$
E\left[C_{r}\right]=C_{r}(P V F) P_{r}
$$

where:

$C_{r}=$ average repair cost, which includes the business interruption loss, $C_{b i}$. The average repair cost is the sum of the material repairs and loss due to business interruption while the repair works are performed.

$P V F=$ present value function (Ang et al., 2005).

$$
P V F=\sum_{n=1}^{\infty}\left[\sum_{k=1}^{n} \Gamma(k, \gamma L) / \Gamma(k, v L)(v / \gamma)^{k}\right](v L)^{n} / n ! \exp (-v L)
$$

where

$v=$ mean occurrence rate of earthquakes that may damage the structure,

$\gamma=$ net annual discount rate,

$L=$ structure life. Also,

$P_{r}=$ probability of repair, defined in a simplified way, as a the probability to reach the allowable limit state, which is in terms of the allowable stress for either the bolted or the welded connection.
Similarly, the business interruption cost, $C_{b r^{\prime}}$ is expressed in terms of the loss of revenue due to the repairs or reconstruction works after the earthquake, assumed to last $T$ years:

$C_{b i}=L_{R}(T)$

where:

$L_{R}=$ loss of revenues per year. The expected cost of injuries is proposed to be:

$E\left[C_{i n j}\right]=C_{I L}\left(N_{i n}\right) P_{f}$

where:

$C_{1 I}=$ average injury cost for an individual

$N_{\text {in }}=$ average number of injuries on a typical steel building in Mexico given an earthquake with a mean occurrence rate $v$.

$P_{f}=$ is the annual failure probability.

For the expected cost related to loss of human lives, the cost corresponding to a life loss, $C_{1 L}$, and the expected number of fatalities, $N_{D}$ are considered. The cost associated with a life loss may be estimated in terms of the human capital approach, which consists in the calculation of the contribution lost, due to the death of an individual, to the Gross Domestic Product during his expected remaining life. The details of this calculation are explained in previous works (Ang et al., 1997). The expected number of fatalities is estimated from a curve previously developed for typical buildings in Mexico, in terms of their plan areas, given an earthquake with a mean occurrence rate $v$ (Ang et al., 1997).

$E\left[C_{f a t}\right]=C_{1 L}\left(N_{D}\right) P_{f}$

In the next section, all the figures are estimated for typical costs in USD for Mexico.

A typical geometry of a building, see figure 1, located on the soft soil of Mexico City is selected to analyze its critical frame under seismic loads. A series of conventional "push-over" analyses were performed to identify the critical frame responses. The typical frame of the building is shown in figure 1.

Statistics of the frame maximum response, at critical joint level, are obtained from the frame analyses subjected to Poissonian earthquakes (with mean occurrence rate $v$ ) as scaled from the seismic hazard curve for Mexico City (Esteva et al., 1989). The intensities excee- 
dance rate is obtained from this reference, then the annual cumulative distribution of intensities and the average exceedance rate are calculated and, finally, with the assumption of Posissonian occurrence, the annual cumulative probability of seismic intensities is obtained.

The calculation process described in the last section is performed to the frame shown in figure 1 and the annual cumulative probability of intensities in the soft soil of Mexico City is obtained from the above mentioned seismic hazard curve. See figure 2 .

The above described response statistics are used as an input to the FEM models of the alternative connections and a Monte Carlo simulation process is performed for each connection model in order to get the

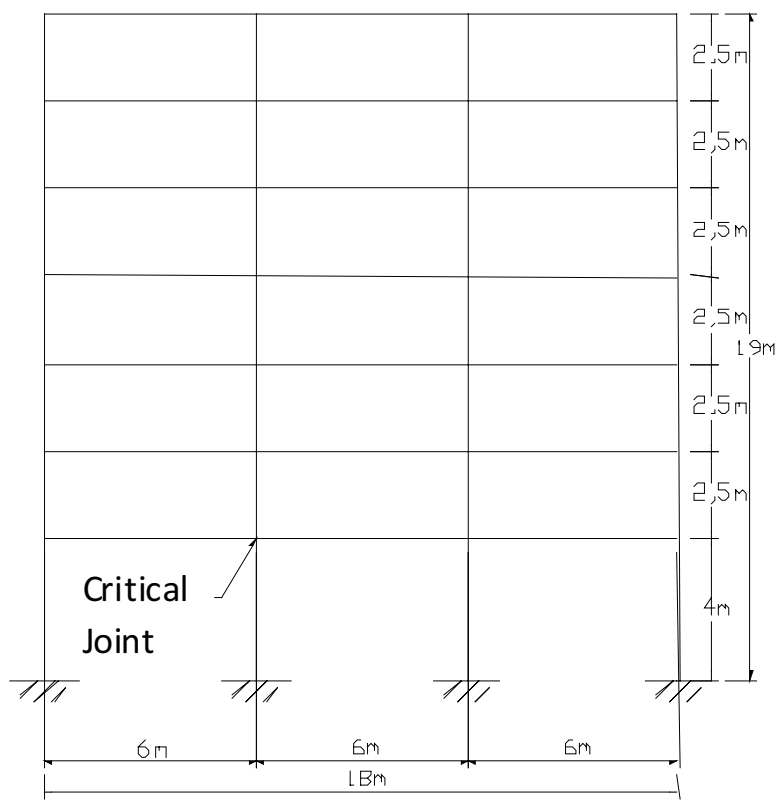

Figure. 1 Typical frame for a steel building in Mexico

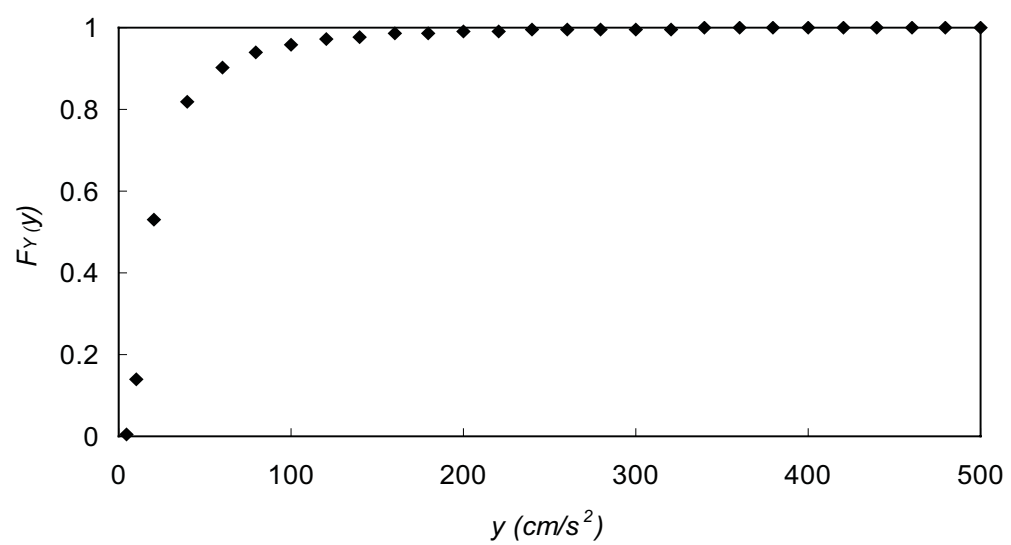

statistics of maximum shear force and moment. With these statistics and the limit state function of each connection, the corresponding failure probabilities are calculated. As an example, $g_{M}{ }^{1}$ and $g_{M}{ }^{2}$ are the limit state functions for maximum moment and for each one of the two alternative connections.

$g_{M}{ }^{1}=M_{r}{ }^{1}-M_{1}$

$g_{M}{ }^{2}=M_{r}^{2}-M_{2}$

where $M_{1}$ and $M_{2}$ are the maximum moments and $\mathrm{M}_{r}{ }^{1}$ and $\mathrm{M}_{r}^{2}$ the resisting moments for the alternative connections 1 and 2, respectively. The corresponding functions for shear force and for the repair probability level are similar.

The expected life-cycle cost of each connection is obtained through the calculated failure probabilities, and equations (1) to (6). The connection type to be recommended will be the one with the minimum life-cycle cost.

\section{Application to a steel building in Mexico}

The plan of the considered building is shown in figure 3 . The building belongs to group $\mathrm{B}$, according to the Mexico City building code (Gobierno del DF, 2004) and the cross sections of the members intersecting at the critical joint, located on the first floor, are shown in table 1.

The building is a regular, framed structure without bracings and the study is made with fixed cross sections, there is no parametric study with variable cross sections. The use of the bulding is for hotel rooms and the structure natural period is $0.58 \mathrm{~s}$. The joint is designed for two options: bolted and welded connection. The bolted option is shown in figure 4 .

The designs were made following standard practices and assuming the application of conventional construction procedures. The annual mean occurrence rate of "significant" earthquakes is 0.142 /year. "Significant", according to the authors experience, are those events that might produce enough damage in the considered building (corresponding to intensities larger than $0.15 \mathrm{~g}$ ).

Figure. 2 Cumulative annual probability of seismic intensities 
Table 1. Cross seccions of beam and column at critical joint

\begin{tabular}{|c|c|}
\hline BEAM: & COLUMN: \\
\hline I section W14X90 & Box Section $16^{\prime \prime} \mathrm{X} 16^{\prime \prime} \mathrm{X} 1 / 2^{\prime \prime}$ \\
\hline
\end{tabular}

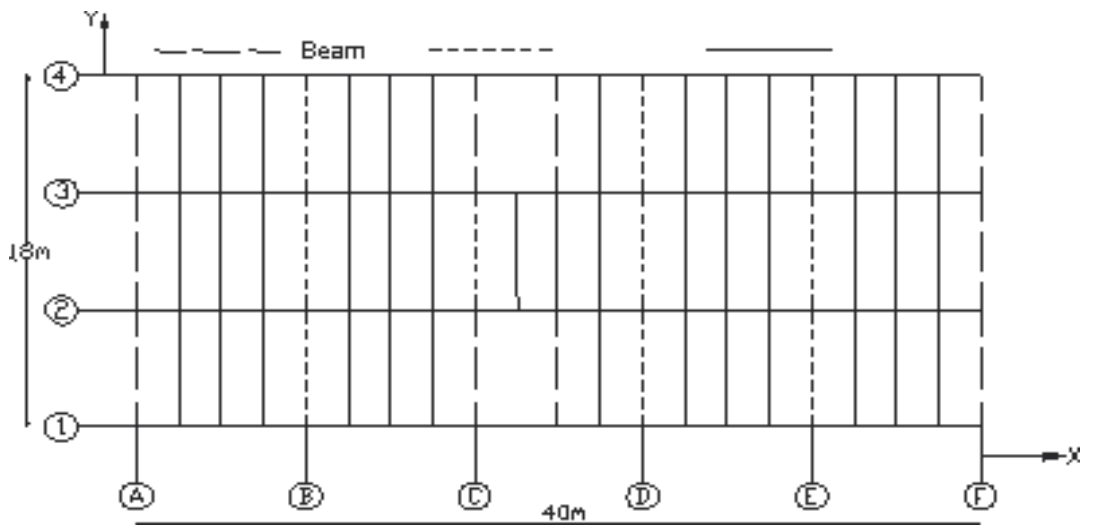

Figure 3. Plan of analyzed building

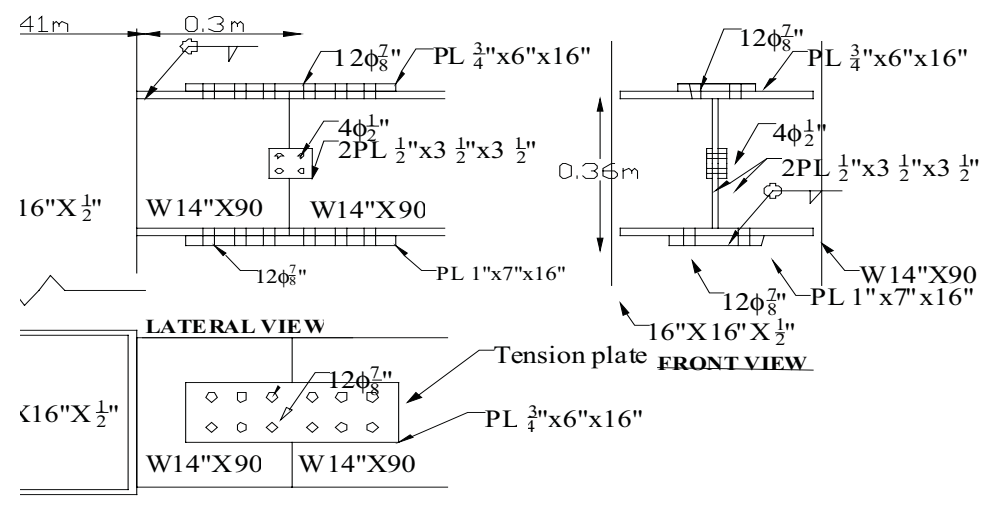

PLAN VIEW

In order to simplify the Monte Carlo simulation process, a series of preliminary structural response analyses were performed for specified spectral acceleration coefficients corresponding to the peak ground accelerations given in the $\mathrm{X}$-coordinates of the curve in figure 2 . The spectral accelerations were: $0.15 \mathrm{~g}, 0.25 \mathrm{~g}, 0.35 \mathrm{~g}$ and $0.45 \mathrm{~g}$ and the maximum moment and maximum shear force were identified. In all cases the critical joints were found to be the first floor connections. These maximum responses were fitted to deterministic functions to be used to randomly generate maximum moments and forces to calculate the repair and failure probability of both
Figure 4. Views of critial joint, bolted option of connection connections. The repair limit states were considered on the basis to exceed the allowable moment and shear force at each connection and these thresholds were calculated for the bolt or welding resistance from the 0.60 of the ultimate stress for the bolt or welding. Shifted gamma distributions were fitted to maximum moments and shear forces. See figures 5 and 6 . In the legend of the $\mathrm{Y}$ axis, "pdf" means probability density function.

The costs and other economic data, for the building, are shown in tables 2 and 3 . It was considered that the worst scenario of human affectation is when all the building occupants die and there are no injuries. 


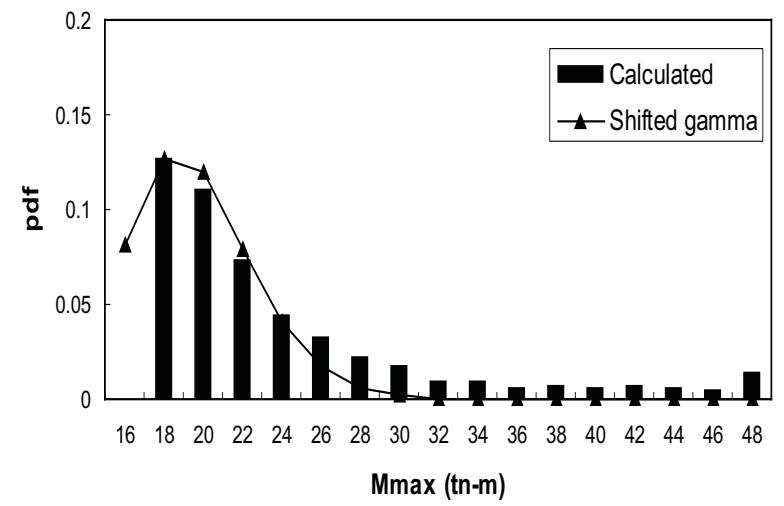

Figure 5. Annual maximum moment distribution for connections
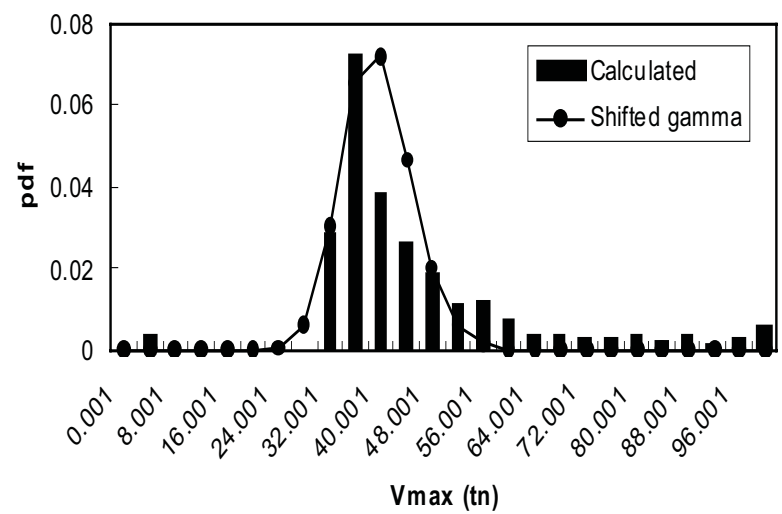

Figure 6. Annual maximum shear force distribution for connections

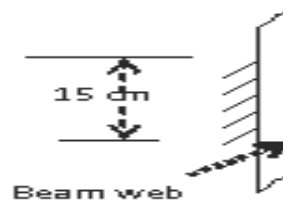

Figure 7. Alternative welded connection

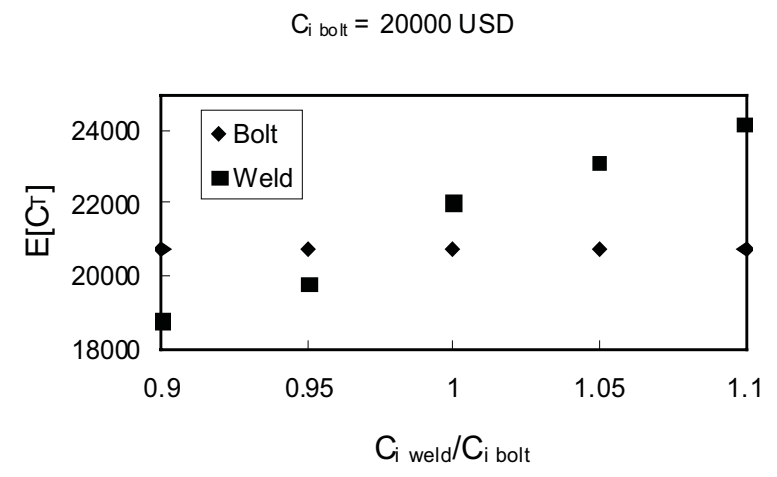

Figure 8. Expected life-cycle cost for several initial costs of welded connection
Table 2. Costs data (USD)

\begin{tabular}{ccc}
\hline Connection & 1 & 2 \\
\hline Ci & 20000 & 22000 \\
Cr & 8000 & 10000 \\
LR & 20000 & 20000 \\
C1i & 10000 & 10000 \\
C1L & 80000 & 80000 \\
\hline
\end{tabular}

Table 3. Other economic data

\begin{tabular}{cc}
\hline$\gamma$ & 0.08 \\
\hline $\mathrm{N}_{\text {in }}$ & 0 \\
$\mathrm{~N}_{\mathrm{D}}$ & 60 \\
$\mathrm{~L}$ & 50 years \\
\hline
\end{tabular}

The second alternative connection is a welded set of 2 fillets with $15 \mathrm{~cm}$ length and $1 / 4$ " thickness with electrodes E70 to join the beam web to the column flanges. A general view of the alternative connections is shown in figure 7 .

The bending mode was found to govern the connection failure. The capacities for moment and shear force, for failure (f) and repair (rep) and for both connections are shown in table 4 . The repair and failure probabilities, for the alternative connections, are shown in table 5 .

With the above obtained failure probabilities, the expected life-cycle costs are calculated and the results are shown in table 6.

\section{Parametric studies}

Two types of connections, bolted and welded, have been designed in such a way that the bending and shear resistances are similar, according to table 4 . The connections Table 4. Capacities for alternative connections

\begin{tabular}{cc}
\hline $\mathrm{Mf}_{1}(\mathrm{tn}-\mathrm{m})$ & $\mathrm{Vf}_{1}(\mathrm{tn})$ \\
69.65 & 108.31 \\
$\mathrm{Mrep}_{1}(\mathrm{tn}-\mathrm{m})$ & $\mathrm{Vrep}_{1}(\mathrm{tn})$ \\
26.19 & 64.986 \\
$\mathrm{Mf}_{2}(\mathrm{tn}-\mathrm{m})$ & $\mathrm{Vf}_{2}(\mathrm{tn})$ \\
70.58 & 115.8 \\
$\mathrm{Mrep}_{2}(\mathrm{tn}-\mathrm{m})$ & $\mathrm{Vrep}_{2}(\mathrm{tn})$ \\
38.748 & 81.48 \\
\hline
\end{tabular}

Table 5. Repair and failure probabilities for alternative connections

\begin{tabular}{cc}
\hline $\operatorname{Pr}_{1 \mathrm{M}}$ & $\mathrm{Pr}_{2 \mathrm{M}}$ \\
\hline $7 . \mathrm{E}-03$ & $2 . \mathrm{E}-06$ \\
$\mathrm{Pf}_{1 \mathrm{M}}$ & $\mathrm{Pf}_{2 \mathrm{M}}$ \\
$2 . \mathrm{E}-07$ & $1 . \mathrm{E}-08$ \\
\hline
\end{tabular}


Table 6. Expected life-cycle costs for alternative connections

\begin{tabular}{ccccccc}
\hline Alternative & $\mathrm{E}\left[\mathrm{C}_{\mathrm{r}}\right]$ & $\mathrm{E}\left[\mathrm{C}_{\mathrm{fat}}\right]$ & $\mathrm{E}\left[\mathrm{L}_{\mathrm{r}}\right]$ & $\mathrm{C}_{\mathrm{i}}$ & $\mathrm{E}\left[\mathrm{C}_{\mathrm{D}}\right]$ & $\mathrm{E}\left[\mathrm{C}_{\mathrm{T}}\right]$ \\
\hline 1 & 630 & 1.87 & $1 . \mathrm{E}+02$ & 20000 & 771.87 & 20771.87 \\
2 & 0.17 & 0.09 & $3 . \mathrm{E}-02$ & 22000 & 0.29 & 22000.29
\end{tabular}

capacity is larger than the capacity of the beam and column which are being connected such that they fulfill the safety requirement that the connection is safer that the connected beam and column. The ultimate capacity of the connections has been considered here although the full nonlinear moment-curvature behavior and ductility is not explicitly included at this stage of the study.

From inspection of the results, it is observed that the initial, repair and economic loss are the costs that dominate the selection of connection type. Therefore, the expected life-cycle cost is assessed for various values of these parameters. The results for several combinations of initial (construction) costs are shown in figure 8 .

It is observed that, if the cost of welding remains below 0.97 times the cost of the bolted connection, the welded connection is the recommended one. However, if the welding exceeds that limit, the connection should be bolted for the minimum expected life-cycle cost.

Now, as far as the repair cost is concerned, the comparison of expected life-cycle costs, for a few combinations of repair costs for the bolted and welded connections proposed, is shown in figure 9.

As observed, whenever the welded connection costs less than 0.4 times the bolted one, it is more economical to do the welded one. And, if this cost exceeds that limit, the bolted one is the one to be recommended. Finally, the impact of the losses due to business interruption (rent, for example) is explored. See figure 10.

It is observed that, for losses up to 200,000 USD, the bolted connection produces the lower expected life-cycle cost. But, for losses higher than that, the welded connection is recommended.

\section{Discussion of results}

From the results obtained in the previous section, it is observed that the optimal connection type is the first one, the bolted connection. The cost items that impacted the most were the initial (construction) cost, the repair cost and the losses due to service (business) interruption. The bending effect is the one that governs the connection design for the case treated here and for the seismic conditions illustrated. This is not always the case and, for other cases of structural type and seismic environment, the governing failure mode should be identified.

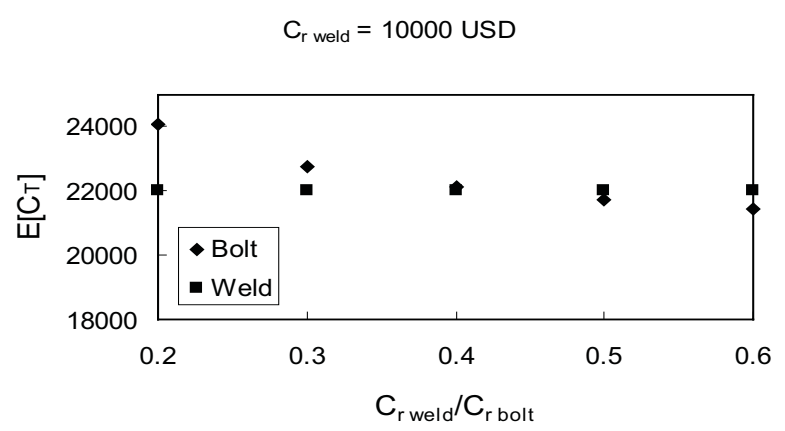

Figure 9. Expected life-cycle cost for several repair costs of bolted connection

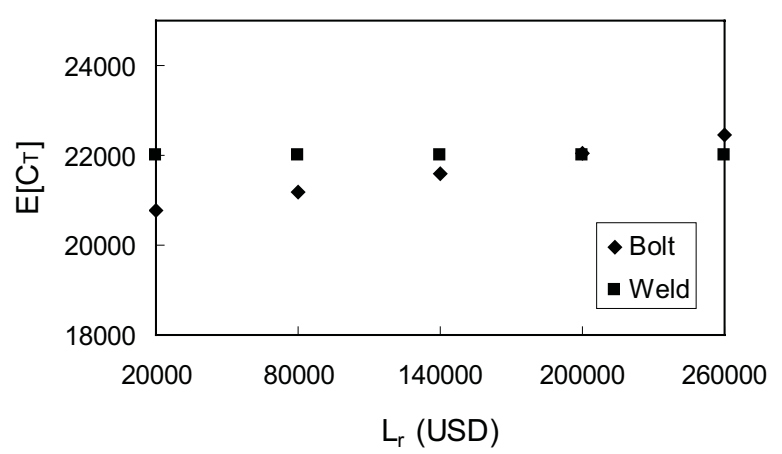

Figure 10. Expected life-cycle cost for several losses due to business interruption

The cost differences regarding the initial and repair costs may be explained because, for the bolted connection part of the work is made on a workshop and the rest in situ and no very special workmanship is required whereas, the welded one makes use of a more qualified (certified) workmanship. It is interesting to note that, for expensive losses due to service interruption, the gain on safety of the welded connection (due to its lower failure probability) offsets the more expensive initial and repair cost. But, for no very expensive service losses, the bolted connection is recommended. Two simple options were included here for illustration purposes. The decision tool may be extended to compare a wide variety of connections and details where the costbenefit analysis is justified. The results are useful for the hazard and site considered. Other conditions require an adaptation of data like, hazard type, seismicity and costs.

\section{Conclusions and recommendations}

A risk-based decision tool has been presented to select potentially feasible connection types in a steel building 
under seismic loads. For the particular building considered here, a bolted connection is preferred, from the cost effectiveness point of view, over a welded one. The bolted connection remains preferred for initial cost of the welded one exceeds 0.97 times the cost of the bolted one, if the repair cost of the welded one exceeds 0.4 time the one of the bolted one and if the losses due to service interruption are less than 200,000 USD. Maximum moments and maximum shear forces are better characterized through shifted gamma distributions.

Further research may lead to a wider range of applications in order to compare design, construction and retrofit alternative schemes. Also, with the analysis of many other structural types, number of stories, natural periods of buildings and a whole range of connection types, including combinations of bolts and welding fillets, the criteria may be used to update the Mexican code for design and retrofit specifications.

In addition to that, the nonlinear behavior of bolted and welded connections should be included to incorporate the peculiar features and advantages of each type of connection regarding ductility and moment vs. curvature relationships.

\section{Acknowledgements}

Mexican construction engineers suggested the connection types, as a common practice on the region. Their contributions are acknowledged and thanked.

\section{References}

AISC. Specification for Structural Steel Buildings. Chicago Illinois, E.U. 2005.

Ang A.H.S., De León D. Determination of Optimal Reliabilities for Design and Upgrading of Structures. Structural Safety, 19(1):91-103. 1997.

Ang A.H.S., De León D. Modeling and Analysis of Uncertainties for Risk-Informed Decisions in Infrastructures Engineering. Journal of Structure and Infrastructure Engineering, 1(1):19-31. 2005.

Ang-Alfredo H.S., Tang W.H. Probability Concepts in Engineering Planning and Design. Vol. I- Basic Principles. $2^{\text {nd }}$. Edition. John Wiley and Sons, New York. 2007.
Ang A.H.S., Tang W.H. Probability Concepts in Engineering Planning and Design. Vol. II-Risk, Reliability and Decisions. John Wiley and Sons, New York. 1984.

Bruneau M., Whitakker A., Uang Ch.M. Ductile Design of Steel Structures. McGraw Hill. 1998.

Esteva L. Behavior Under Alternating Loads of Masonry Diaphragms Framed by Reinforced Concrete Members. Proc. International Symposium on the Effects of Repeated Loading of Materials and Structures. RILEM, México City. 1966.

Esteva L., Ruiz S. Seismic Failure Rates of Multistory Frames. Journal of Structural Engineering, ASCE, 115(2): 268-284. 1989.

FEMA 273. NEHRP Guidelines for the Seismic Rehabilitation of Buildings. 1997.

Gobierno del DF. Normas Técnicas Complementarias para Diseño y Construcción de Estructuras Metálicas, México DF, 2004.

IMCA. Memorias V Simposio Internacional de Estructuras de Acero, Guadalajara, Jal. 1997.

Miranda E. Plate-end Connection for Steel Buildings in Mexico. Memorias V Simposio Internacional de Estructuras de Acero, Guadalajara, Jal. 1997a.

Miranda E. Seismic Design of Beam-Column Connections. Memorias V Simposio Internacional de Estructuras de Acero, IMCA, Guadalajara, Jal. 1997b.

Miranda E., Martínez R.E.Seismic Design Recommendations for Steel Structures with Eccentrically-Braced Frames in México. Memorias VI Simposio Internacional de Estructuras de Acero, Puebla. 1999.

Neves L.C., Frangopol,D.M., Hogg V. Condition-Reliability-Cost Interaction in Bridge Maintenance. ICASP9, San Francisco, CA. 2003.

Righiniotis T.D., Imam B. Fracture Reliability of a Typical Northridge Steel Moment Resisting Connection. Engineering Structures. Vol. 26, Issue 3, pp 381-390, School of Engineering, University of Surrey, Guildford, Surrey GU2 7XH, UK. 2004.

SAC Project [on line]. 1994 Available on: http://quiver.eerc.berkeley. edu:8080/library/index.html

Wen Y.K., Fouth D.A. Proposed Statistical and Reliability Framework for Comparing and Evaluating Predictive Models for Evaluation and Design and Critical Issues in Developing such Framework. Report No. SAC/BD-97/03, SAC Joint Venture. Sacramento California. 1997. 


\section{About the authors}

David de León-Escobedo. Ph. D. in Engineering (1991-1996), University of California, Irvine. Professional Engineer in California (Civil Engineering) since 1996. Project Engineer LATISA, México, D. F. Detail Engineering for SICARTSA plant in Lázaro Cárdenas, Mich. From 1983 to 1984. Project engineer in the company W. Koo and Associates. Bridge design and assessment for CALTRANS, Orange, California, from 1996 to 1997. Project engineer at IMP (Mexican Petroleum Institute): Risk and reliability assessment for marine offshore platforms, vibration assessment of platforms, safety and code assessment for oil pipelines, mediation for construction controversy between SCT about the Chiapas-Malpaso bridge, from 1999 to 2005. Professor at UAEM, Engineering School, since 2005.

Alfredo Reyes-Salazar. PhD in Engineering (1993-1997), University of Arizona in Tucson. Consulting Engineer Since 1997. Member of the Academy of Civil Engineers of Sinaloa (2005-to date). Member of the College of Civil Engineers of Sinaloa (2003-to date). Professor-Researcher in The Universidad Autónoma de Sinaloa (1988-to date). Professor at The Monterrey Technology Institute in Sinaloa (1992-1993). Member of the Researcher National System, Level 1 (2000-to date). More than 40 presentations in national and international congresses. Thirteen publications in internationally arbitrated journals.. 